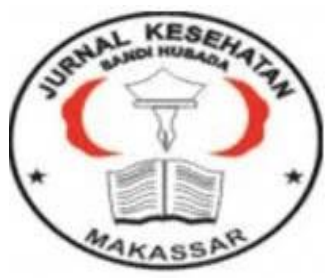

Jurnal Ilmiah Kesehatan Sandi Husada

hhttps://akper-sandikarsa.e-journal.id/JIKSH

Volume 9, Nomor 2, Desember 2020, pp 735-740

p-ISSN: 2354-6093 dan e-ISSN: 2654-4563

DOI: $10.35816 /$ jiskh.v10i2.396

\title{
Buah Plum Sebagai Pencegah Kejadian Preeklampsia Pada Kehamilan
}

Plum as Prevention of Preeclampsia in Pregnancy

Farhan Dzaki Alfahri

Fakultas Kedokteran Universitas Lampung

\section{Artikel info}

Artikel history:

Received; Juli 2020

Revised: Agustus 2020

Accepted; Agustus 2020

\begin{abstract}
Abstrak
Setiap tahun terdapat 10 juta wanita hamil mengalami preeklampsia dengan jumlah kematian bayi akibat kehamilan dengan preeklampsia mencapai 500.000 bayi per tahun. Terdapat kira-kira 76.000 wanita hamil meninggal akibat preeklampsia dan penyakit terkait hipertensi. Preeklampsia merupakan sindrom spesifik kehamilan berupa berkurangnya perfusiorgan akibat vasospasme dan disfungsi endotel. Peningkatan permeabilitas kapiler, peningkatan faktor koagulasi, peningkatan bahan vasopressor dan penurunan kadar vasodilator seperti nitrit oksida (NO). Salahsatu senyawa yang dapat meningkatkan kadar NO adalah Flavonoid yang banyak ditemukan dalam buah plum. Defisiensi NO pada ibu hamil memiliki peran penting dalam terjadinya preeklampsia. Peningkatan NO pada ibu hamil sedang gencar dilakukan untuk mencegah terjadinya preeclampsia. Kandungan dalam buah plum ini memiliki fungsi berupa peningkatan fungsi endotel dan penurunan tekanan sistolik dan diastolik. Sehingga dengan mengonsumsi buah plumdapat mencegah terjadinya preekslampsia pada kehamilan.
\end{abstract}

\section{Abstract.}

Every year there are 10 million pregnant women who experience preeclampsia with the number of pregnancy babies dying with preeclampsia reaching 500,000 babies year. Approximately 76,000 pregnant women died from preeclampsia and hypertension-related diseases. Preeclampsia is a blood pressure of at least $140 \mathrm{mmHg}$ systolic or $90 \mathrm{mmHg}$ diastolic at two tests corresponding to 15 minutes using the same with urine protein increased $300 \mathrm{mg}$ in 24 hours or urine dipstick test> positive 1 and liver, neurological dysfunction. neurological, uteroplacental circulation, pulmonary edema, thrombocytopenia after 20 weeks of gestation. Preeclampsia is a pregnancy syndrome in the form of a lack of organ perfusion due to vasospasm and 


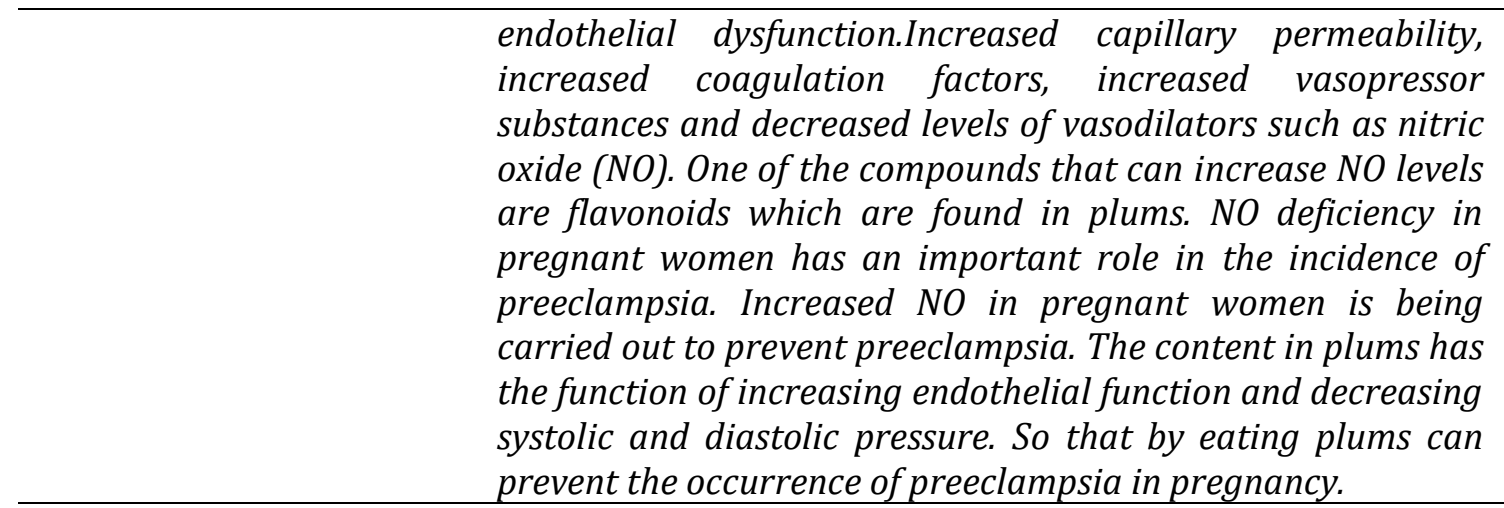

Keywords:

Plums;

Coresponden author:

Antioxidants;

Preeclampsia;

Email: $\underline{\text { arhandzakialfahri@gmail.com }}$

artikel dengan akses terbuka dibawah lisensi CC BY 4.0

\section{Pendahuluan}

Setiap tahun terdapat 10 juta wanita hamil mengalami preeklampsia dengan jumlah kematian bayi akibat kehamilan dengan preeklampsia mencapai 500.000 bayi per tahun. (Schindler \& Schindler, 2018). Selain merupakan salah satu penyabab utama kematian ibu, preeklampsia juga mempunyai kontribusi yang besar terhadap kematian janin dan berat bayi lahir rendah karena terkait asfiksia dan prematuritas (Saleem dkk., 2014). Angka kematian ibu di Indonesia berdasar hasil survei penduduk antar sensus tahun 2015 adalah 305/100.000 kelahiran hidup, artinya dari 100.000 kelahiran terdapat 305 kematian ibu. (Badan Pusat Statistik, 2015) Angka tersebut merupakan tertinggi ke dua setelah Laos di Asia Tenggara dengan 9 kali lebih tinggi dibanding Malaysia, 5x kali lebih tinggi dibanding Vietnam dan hampir 2x lebih tinggi dibanding Kamboja (ASEAN Secretariat, 2017).

Preeklampsia adalah tekanan darah sekurang-kurangnya $140 \mathrm{mmHg}$ sistolik atau 90 mmHg diastolic pada dua kali pemeriksaan berjarak 15 menit menggunakan lengan yang sama dengan protein urin melebihi $300 \mathrm{mg}$ dalam 24 jam atau tes urin dipstick >positif 1 dan/atau disfungsi ginjal, liver, neurologis, sirkulasi uteroplasenta, edema paru, trombosititopenia yang timbul setelah usia kehamilan 20 minggu. (Wilkerson RG \& Ogunbodede AC, 2019) (Sutton ALM, etal, 2018) Sampai saat ini belum ada teori yang menjelaskan penyebab pasti terjadinya preeklampsia. Salah satu teori yang menjelaskan etiologi ini adalah adanya disfungsi endotel yang ditandai dengan kadar Vascular Endothelial Growth Factor (VEGF) yang lebih rendah dibanding wanita hamil yang normal atau wanita tidak hamil. (Adu-bonsaffoh, etal, 2017) Disfungsi endotel menyebabkan terjadinya peningkatan permeabilitas kapiler, peningkatan faktor koagulasi, peningkatan bahan vasopressor dan penurunan kadar vasodilator seperti nitrit oksida (NO). (Wikjonosastro, dkk, 2010).

Defisiensi NO pada ibu hamil memiliki peran penting dalam terjadinya preeklampsia (Dymara-konopka, 2019). Peningkatan NO pada ibu hamil sedang gencar dilakukan untuk mencegah terjadinya preeklampsia (Duarte J, etal, 2014). Salahsatu senyawa yang dapat meningkatkan kadar NO adalah Flavonoid yang banyak ditemukan dalam buah plum (Cosmulescu, S,. dkk, 2015). Berdasarkan hal tersebut, maka artikel ini akan membahas tentang buah plum sebagai pencegah kejadian preeklampsia pada kehamilan. 


\section{Metode}

Metode ini menggunakan studi pustaka dengan mengambil data dan referesi dari berbagai buku dan artikel ilmiah yang valid. Artikel tersebut ddicari melalui data dari (PubMed, BMC, Google cendikia). Data diambil dengan menggunakan kata kunci: plum, preeclampsia, flavonoid. Selanjutnya literature melewati proses review dengan kriteria. Data yang sesuai dengan kriteria kemudian akan disusun dalam literature review ini.

\section{Hasil Dan Pembahasan}

Berdasarkan studi epidemiologi menunjukkan bahwa mengkonsumsi buah, sayur dan produknya memiliki manfaat kesehatan dalam mencegah penyakit kronis termasuk penyakit kardiovascular dan beberapa jenis kanker. (Khoo et al, 2016). Plum adalah kelompok spesies yang beragam, berasal dari Eropa. Buah-buahan yang menampilkan berbagai ukuran, warna, rasa dan tekstur. Biasanya membentuk semak besar atau pohon kecil. Sedikit berduri, dengan bunga putih, buah berwarna ungul oval atau bulat bervariasi dalam ukuran, tetapi bisa sampai $8 \mathrm{~cm}$, dan biasanya manis. Plum dikenal dengan manfaatnya yang menarik, terutama, sebagai obat pencahar dan anti-tumor (Belhadj \& Marzouki, 2014). Buah plum memiliki banyak manfaat dalam bidang kesehatan, diantaranya sebagai antibakteri, antioksidan, antihemolitik, antiinflamasi dan antikanker (Islam et al., 2017). Aktivitas antibakteri pada ekstrak plum sudah diketahui sejak lama. Efek menguntungkan dari buah ini dianggap berasal dari aktivitas senyawa fenolik seperti asam fenolik, flavonoid, tanin, dan senyawa nitrogen seperti alkaloid dan amina, serta vitamin, terpenoid dan lainnya metabolit, yang memiliki aktivitas antioksidan tinggi (Abdel-Rahim dkk, 2010).

Menurut klasifikasi biologi plum adalah ordo Rosales, family Rosacease, subfamily Amygdaloidae, genus Prunus, subgenus Prunus. Di Indonesia terdapat hampir 2000 spesies buah plum yang terdiri atas berbagai ukuran dan warna seperti kuning, putih, hijau atau merah. Buah plum memiliki tampilan lapisan berdebu putih yang memberikan penampilan sayu. (Birwal dkk, 2017). Plum memiliki berbagai manfaat dalam pengobatan. Hal ini dikarenakan plum memiliki kandungan senyawa metabolit sekunder yang berperan sebagai antibakteri. Berdasarkan penelitian yang dilakukan oleh Alam dan Rajesh, terdapat beberapa kandungan zat aktif yang berperan sebagai antibakteri pada buah plum diantarnya senyawa tanin, flavonoid dan alkaloid yang dapa bertindak sebagai anti oksidan maupun antibakteri (Jahangir dkk, 2015). Selain itu, juga terdapat zat aktif saponin total fenol $1.05 \mathrm{mg}$ GAE/100mg ekstrak, total flavonoid $0.583 \mathrm{mg}$ CE/100 mg ekstrak, alkaloid 9.4\%, Saponin 0,4\% (Soni dkk, 2014).

Dalam bidang kesehatan, flavonoid berperan sebagai anti bakteri, anti oksidan, anti inflamasi, dan anti diabetes (Panche dkk, 2016). Dalam perkembangannya, hingga tahun 2011 ditemukan lebih dari 9000 flavonoid dan telah digunakan untuk suplemen kesehatan (Wang dkk, 2018). Flavonoid dibagi menjadi beberapa subkelompok berdasarkan substitusi karbon pada gugus aromatik sentral (C). Subkelompok tersebut adalah: flavon, flavonols, flavanone, flavanol/ katekin, antosianin dan kalkon (Wang dkk., 2016). Penelitian oleh Silvan dkk (2020) menunjukkan bahwa bubuk ekstrak plum yang diperoleh setelah pembekuan, vakum, dan pengeringan memiliki sifat antibakteri, antioksidan, dan anti-inflamasi yang telah diuji dalam model biologis yang berbeda. Serbuk ini juga dapat menginduksi perlindungan seluler terhadap stres oksidatif dengan mencegah akumulasi ROS intraseluler, tetapi tingkat kapasitas antioksidan dapat ditentukan oleh kondisi yang diterapkan selama proses pengeringan (Silvan dkk, 2020). 
Penelitian yang dilakukan oleh Miletic dkk (2013) menyatakan bahwa didapatkan korelasi yang signifikan antara konstituen buah fenolik dan kapasitas antioksidan plum dan plum dari kedua kultivar yang diteliti, menyimpulkan adanya pengaruh yang kuat anthocyanin, flavonoid dan polifenol terhadap antioksidan (Miletic dkk, 2015).

Flavonoid erat kaitannya dengan antioksidan karena memiliki kemampuan untuk memecah radikal bebas. Mekanisme pencegahan radikal bebas oleh flavonoid dapat dibagi menjadi tiga yaitu: memperlambat pembentukan Reactive Oxygen Species (ROS), memecah ROS dan meregulasi/proteksi dengan antioksidan. Penelitian lebih lanjut oleh Procházková dkk (2011) menunjukan flavonoid juga menstimulasi enzim antioksidan internal, supresi enzim terkait pembentukan radikan bebas, dan mengikat logam. Gugus hidroksi yang terdapat pada cincin B dianggap mempunyai peran penting dalam pemecahan ROS (Procházková dkk, 2011).

Menurut Sangeetha et al. (2016) gugus hidroksil diyakini yang paling berperan dalam proses pemecahan radikal bebas karena dapat melakukan proses donor hidrogen. Hal ini juga didukung oleh penelitian Korkina \& Afanasev, yang menyatakan gugus hidroksi pada flavonoid memiliki reaktivitas yang tinggi sebagai donor hidrogen akan menstabilkan radikan bebas. Kapasitas flavonoid sebagai antioksidan secara in vitro telah dibuktikan dengan banyak studi penunjang bertahun-tahun kebelakang dan dianggap potensial untuk dilakukan pengembangan pada industri obat maupun makanan (Sangeetha dkk, 2016; Panche et al., 2016). menunjukan proses pemecahan ROS yang melibatkan gugus hidroksi pada cincin aromatik B yang mendonorkan hidrogen dan elektron kepada gugus radikal hidroksil, peroksil dan peroksinitrat menjadi tidak berbahaya (Kumar dkk, 2013)

Radikal nitrat oksida (NO) dikenal karena memiliki peran penting dalam berbagai jenis proses inflamasi. Produksi radikal nitrat oksida pada tingkat yang berkelanjutan menghasilkan toksisitas jaringan langsung dan berkontribusi terhadap kolapsnya pembuluh darah yang terkait dengan syok septik, sedangkan ekspresi kronis radikal NO dikaitkan dengan berbagai karsinoma dan kondisi inflamasi termasuk diabetes, sklerosis multipel, artritis dan ulcerative colitis. Nitrit oksida yang dihasilkan dari sodium nitroprusside bereaksi dengan oksigen untuk membentuk nitrit. Ekstrak buah juga menghambat pembentukan nitrit dengan bersaing secara langsung dengan oksigen untuk bereaksi dengan NO (Singh et al, 2017). Plum tradisional Eropa mengandung jumlah yang tinggi asam fenolik, flavonoid, karoten, vitamin dengan antioksidan tinggi aktivitas, lebih tinggi dari jeruk dan stroberi. Meskipun tidak memiliki warna biru-hitam yang khas, juga memiliki kandungan fenolik dan antioksidan yang tinggi. Senyawa fenolik yang ada adalah isomer asam caffeoylquini yang meliputi asam neoklorogenik, asam kriptoklorogenik, dan klorogeni asam. Asam neoklorogenik adalah yang paling melimpa senyawa fenolik dan telah dilaporkan sebagai salah satu radikal bebas yang baik (Dinardo dkk, 2017).

Preekslampsia adalah hipertensi yang timbul setelah usia kehamilan 20 minggu disertai dengan proteinuria. Preeklampsia merupakan penyulit kehamilan yang akut dan dapat terjadi ante, intra dan postpartum (Carolia dkk, 2016). Berdasarkan gambaran klinis, preeklampsia terbagi atas dua jenis, yaitu preeklampsia ringan dan preeklampsia berat.Gambaran klinik yang timbul pada preeklampsia secara berurutan adalah edema, hipertensi, dan terakhir proteinuria. Jika gejala-gejala tersebut timbul tidak berurutan dapat dianggap bukan preeclampsia (Carolia dkk, 2016).Beberapa gejala tersebut timbulnya hipertensi dan proteinuria merupakan gejala yang paling penting. Apabila sudah mengeluh adanya gangguan nyeri kepala, gangguan penglihatan atau nyeri epigastrium, maka penyakit ini sudah cukup lanjut (Carola dkk, 2016). 
Konsentrasi buah dan sayuran yang tinggi telah berkorelasi dengan penurunan penyakit kardiovaskular. Beberapa penelitian tidak hanya meneliti mengenai antioksidan terkandung dalam buah-buahan dan sayuran yang memiliki manfaat kesehatan seperti menurunkan tekanan darah sistolik dan diastolic. Bainiku-ekisu, konsentrat jus buah Plum Asia, mewakili potensi baru agen terapi untuk penyakit kardiovaskular seperti hipertensi dan aterosklerosis (Ahmed dkk, 2010). Konsentrat jus buah dariprem oriental (Pru nus mume) baru-baru ini terbukti meningkatkan fluiditas darah manusia. Bainiku-ekisu, mungkin bermanfaat melawan hipertensi dan aterosklerosis dengan menghambat pertumbuhan secara selektif membawa sinyal Angiotensin-II di pembuluh darah. Penelitian eksperimental yang mendukung peran sebagai stres oksidatif pada cedera vaskular dan hipertensi. Suplementasi antioksidan, terutama dalam bentuk buah segar dan sayuran, mengurangi tekanan darah, mendukung peran radikal bebas dalam hipertensi (Ahmed dkk, 2010).

Plum memiliki banyak bioaktif senyawa seperti asam fenolik, antosianin, karotenoid, flavanol, organic asam, (mis., asam sitrat dan malat), serat (pektin), tanin, zat aromatik, enzim, mineral (mis., kalium, fosfor, kalsium dan magnesium, organik) dan vitamin A, B, C $\&$ K. Senyawa fenol yang dominan dalam plum adalah kafein asam, 3-0-caffeicquinic (asam neoklorogenik), 5-0-caffeicquinic (asam klorogenik) dan 4-0-caffe-icquinic (asam kriptoklorogenik). Plum digunakan dalam bahasa India obat sebagai komponen obat alami yang digunakan dalam kasus keputihan, tidak teratur menstruasi dan keguguran. Plum membantu dalam pencegahan penyakit jantung, paru-paru dan kanker mulut, menurunkan gula darah, tekanan darah, penyakit Alzheimer, degenerasi otot, meningkatkan kapasitas memori, meningkatkan kesehatan tulang, mengatur fungsi sistem pencernaan dan sebagainya (Birwal dkk, 2017). Penelitian oleh Carolia (2016) menunjukkan bahwa coklat hitam merupakan coklat yang banyak memiliki efek terhada kardiovaskular karena memiliki kandungan flavonoid dan theobromine yang tinggi. Kandungan dalam coklat hitam in memiliki fungsi berupa peningkatan fungsi endotel dan penurunan tekanan sistolik dan diastolik. Sehingga denga mengonsumsi coklat hitam dapat mencegah terjadinya preekslampsia pada kehamilan (Carolia dkk, 2016). Sama halnya dengan penelitian Khairunnisa (2020) menyatakan bahwa cokelat hitam memiliki kadar flavonoid yang tinggi. Flavonoid dalam cokelat hitam dapat membantu untuk meningkatkan kadar nitrit oksida sehingga mencegah terjadinya disfungsi endotel mencegah terjadinya preeclampsia (Khairunnisa, 2020).

\section{Simpulan Dan Saran}

Buah plum memiliki banyak manfaat dalam bidang kesehatan, diantaranya sebagai antibakteri, antioksidan, antihemolitik, antiinflamasi dan antikanker. Aktivitas antioksidan pada senyawa flavonid dapat penurunan tekanan sistolik dan diastolik. Sehingga dengan mengonsumsi buah plum dapat mencegah terjadinya preekslampsia pada kehamilan. Oleh karena itu, disarankan kepada ibu hamil untuk mengkonsumsi buah plum mengingat buah plum dapat mencegah terjadinya peningkatan tekanan darah pada saat kehamilan.

\section{Daftar Rujukan}

Adu-bonsaffoh, K., Antwi, D. A., Gyan, B., \& Obed, S. A. (2017). Endothelial dysfunction in the pathogenesis of pre-eclampsia in Ghanaian women. 1-8. https://doi.org/10.1186/s12899-017-0029-4

Ahmed, T., Sadia, H., Batool, S., Janjua, A., \& Shuja, F. (2010). Use of prunes as a control of hypertension. 22(1), 28-31.

ASEAN Statistical Report on Millennium Development Goals 2017. (2017). 
Birwal, P., Deshmukh, G., Sp, S., \& Pragati, S. (2017). iMedPub Journals Plums : A Brief Introduction Abstract Health-Promoting Properties of Plums Antioxidant and Total Phenolic content of Plums Phenolic compounds are fascinating and unique class of bioactive. 1-5.

Carolia, N., Gde, L., Ayuning, I., Farmakologi, B., Kedokteran, F., Lampung, U., ... Lampung, U. (2016). Coklat Hitam untuk Mencegah Preeklampsia pada Kehamilan Dark Chocolate to Prevent Preeclampsia in Pregnancy. 5, 59-62.

Cosmulescu, S., Trandafir, I., Nour, V., \& Botu, M. (2015). Total Phenolic , Flavonoid Distribution And Antioxidant Capacity In Skin , Pulp And Fruit Extracts Of Plum Cultivars. 39(2012), 64-69. https://doi.org/10.1111/jfbc.12112

Dinardo, A., Subramanian, J., Singh, A., \& Dinardo, A. (2017). Investigation of Antioxidant Content and Capacity in Yellow European Plums Investigation of Antioxidant Content and Capacity in Yellow European Plums. International Journal of Fruit Science, 00(00), 1-18. https://doi.org/10.1080/15538362.2017.1381873

Duarte, J., Francisco, V., \& Perez-Vizcaino, F. (2014). Modulation of Nitric Oxide by Flavonoid. 5, 1653-1668. https://doi.org/10.1039/C4JA00138A

Dymara-konopka, W. (2019). The Role of Nitric Oxide , ADMA, and Homocysteine in The Etiopathogenesis of Preeclampsia -Review. (Figure 1), 1-19.

El-beltagi, H. (2016). Constituents of apple, parsley and lentil edible plants and their therapy treatments for blood picture as well as liver and kidneys functions against lipidemic disease Constituents Of Apple, Parsley And Lentil Edible Plants And Their Therapy Treatments For Blood Picture As Well As Liver And Kidneys Functions. (October).

Khairunnisa, L. (2020). Konsumsi Cokelat Hitam Untuk Mencegah Preeklampsia. Jurnal Ilmiah Kesehatan Sandi Husada, 11(1), 517-521. https://doi.org/10.35816/jiskh.v10i2.341

Saleem, S., Mcclure, E. M., Goudar, S. S., Patel, A., Esamai, F., Garces, A., ... Wright, L. L. (2014). A prospective study of maternal, fetal and neonatal deaths in low- and middle-income countries. (March), 605-612.

Schindler, A. E., \& Schindler, A. E. (2018). New data about preeclampsia : some possibilities of prevention. Gynecological Endocrinology, 34(8), 636-637. https://doi.org/10.1080/09513590.2018.1441401

Wikjnosastro, Saiffudin AB \& Rachimidhiani T. (2010). Ilmu Kebidanan. Edisi ke-4. Jakarta: Yayasan Bina Pustaka Sarwono Prawirohardjo.

Wilkerson RG \& Ogunbodede AC. (2019). Hypertensive Disorder of Pregnancy. Emergency Medicine Clinics of North America. 37(2):301-316 